\title{
Antiurolithiatic Activity of Daucus carota: An in vitro Study
}

\author{
Sweta Bawari, Archana Negi Sah*, Devesh Tewari
}

\section{Sweta Bawari, Archana Negi Sah*, Devesh Tewari}

Department of Pharmaceutical Sciences, Faculty of Technology, Bhimtal Campus, Kumaun University, Nainital - 263136, Uttarakhand, INDIA.

Correspondence

Dr. Archana Negi Sah

Department of Pharmaceutical Sciences, Faculty of Technology, Bhimtal Campus, Kumaun University, Nainital - 263136,

Uttarakhand, INDIA.

Phone no: 9410566599

E-mail: drarchanansah@gmail.com

History

- Submission Date: 12-05-2018;

- Review completed: 04-06-2018

- Accepted Date: 11-07-2018

DOI : 10.5530/pj.2018.5.148

Article Available online

http://www.phcogj.com/v10/i5

Copyright

(C) 2018 Phcog.Net. This is an openaccess article distributed under the terms of the Creative Commons Attribution 4.0 International license.

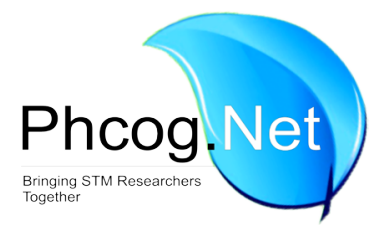

\begin{abstract}
Context: Urolithiasis is a polygenic disorder with complex etiology and even complicated treatment outcomes. Daucus carota is a widely cultivated crop with traditional claims for its antiurolithiatic potential. Aim: Present study was an attempt to investigate the antilithic potential of $D$. carota root extract (DCRE) against calcium oxalate $(\mathrm{CaOx})$ urolithiasis by employing in vitro methods. Methods: Nucleation, growth and aggregation assay of $\mathrm{CaOx}$ crystallization were used. FT-IR analysis was used for characterizing CaOx crystals. Results: DCRE exhibited significant inhibition of nucleation, growth and aggregation of $\mathrm{CaOx}$ crystals. It produced a favorable morphological transformation of $\mathrm{CaOx}$ crystals from calcium oxalate monohydrate to calcium oxalate dihydrate. FT-IR analysis confirmed formation of calcium oxalate monohydrate crystals to be utilized for growth and aggregation assays. Conclusion: DCRE possesses significant antiurolithiatic activity against $\mathrm{CaOx}$ urolithiasis in vitro which could be attributed to its saponins, tannins, flavonoids and polyphenolic content.
\end{abstract}

Key words: Aggregation, Flavonoids, FT-IR, Nucleation, Urolithiasis.

\section{INTRODUCTION}

Urolithiasis is a multifaceted urologic condition that requires frequent emergency department visits and immediate urological intervention. ${ }^{1}$ Technological advancement witnessed for the removal of stones has been outstanding, but the associated complexities like, their tendency to enhance stone recurrence is a major limiting factor. ${ }^{2}$

Development of plant-based medicine as alternative or complementary to the conventional system of medicine have drawn tremendous attention and serves as an immense source of new drug entities. ${ }^{3}$ Based on these grounds, carrots (Daucus carota L., family Apiaceae) were selected for the present study. Carrots are considered functional food and are widely cultivated all around the globe as well as are extensively exploited commercially. Carrots are of high nutritional value and are a rich source of phenolics, polyacetylenes and carotenoids. ${ }^{4}$ Despite their established nephroprotective role $^{5}$ as well as traditional claims for their antilithic potential, ${ }^{6}$ no screening has been carried out so far to establish the antiurolithiatic efficacy of $D$. carota. Therefore, current investigation was carried out for the screening of the antilithic potential of $D$. carota against calcium oxalate crystallization in an in vitro setting.

\section{MATERIALS AND METHODS}

\section{Plant collection}

Daucus carota L. roots (carrots) were procured from a grocery store of Bhimtal, Uttarakhand and were identified and authenticated from Botanical Survey of India (BSI), Dehradun. A voucher specimen of $D$. carota (accession number 116593) was also deposited in the herbarium of BSI.

\section{Processing and extraction}

D. carota roots were cut into thin slices, shade dried, and finely powdered. Cold maceration method was employed for the extraction of powdered carrot roots with $70 \% \mathrm{v} / \mathrm{v}$ ethanol. D. carota root extract (DCRE) thus obtained was dried in a rotary evaporator under reduced temperature and pressure. ${ }^{7}$

\section{Preliminary phytochemical screening}

Preliminary phytochemical evaluation of DCRE was carried out for qualitative estimation of phytoconstituents. $^{8}$

\section{Nucleation assay}

Effect of DCRE on calcium oxalate (CaOx) crystal formation was determined by means of nucleation assay. Calcium chloride $\left(\mathrm{CaCl}_{2}\right)(5 \mathrm{mmol} / \mathrm{l})$ and sodium oxalate $\left(\mathrm{Na}_{2} \mathrm{C}_{2} \mathrm{O}_{4}\right)$ solution $(7.5 \mathrm{mmol} / \mathrm{l})$ were prepared in Tris- $\mathrm{HCl}(0.05 \mathrm{~mol} / \mathrm{l})$ and $\mathrm{NaCl}$ (0.15 mol/l) buffer ( $\mathrm{pH}$ 6.5). Dilutions of DCRE ranging from $100-1000 \mu \mathrm{g} / \mathrm{ml}$ were prepared in distilled water. One milliliter of each DCRE concentration was mixed with $3 \mathrm{ml} \mathrm{CaCl}$, solution followed by the addition of $3 \mathrm{ml} \mathrm{Na} \mathrm{C}_{2} \mathrm{O}_{4}$ solution. Final mixtures were incubated for $30 \mathrm{~min}$ at $37^{\circ} \mathrm{C}$. The optical density (OD) of the mixtures was then measured at $620 \mathrm{~nm}$ wavelength. Percent inhibition of nucleation by DCRE was calculated using the under mentioned formula and compared to that calculated for the standard polyherbal drug, Cystone. ${ }^{9}$ 


$$
\% \text { Inhibition }=\left(1-\frac{\mathrm{OD}_{\text {Test }}}{\mathrm{OD}_{\text {Control }}}\right) \times 100
$$

\section{Microscopic evaluation}

Number, size and morphology of $\mathrm{CaOx}$ crystals formed in absence or presence of DCRE were determined using a Leica DM 2500 LED microscope at $1000 \times$ magnification.

\section{Aggregation assay}

Effect of DCRE on CaOx crystal aggregation was determined by means of aggregation assay. $\mathrm{CaCl}_{2}$ and $\mathrm{Na}_{2} \mathrm{C}_{2} \mathrm{O}_{4}$ solutions ( $50 \mathrm{mmol} / \mathrm{l}$ each) were mixed together, heated to $60^{\circ} \mathrm{C}$ in a water bath for $1 \mathrm{~h}$ and then incubated overnight at $37^{\circ} \mathrm{C}$ to prepare seed $\mathrm{CaOx}$ crystals. After drying, $\mathrm{CaOx}$ crystal solution $(0.8 \mathrm{mg} / \mathrm{ml})$ was prepared in a $0.05 \mathrm{~mol} / \mathrm{l}$ Tris- $\mathrm{HCl}$ and $0.15 \mathrm{~mol} / \mathrm{l} \mathrm{NaCl}$ buffer ( $\mathrm{pH} 6.5)$. One milliliter of aliquots $(100-1000 \mu \mathrm{g} / \mathrm{ml})$ of DCRE were added to $3 \mathrm{ml} \mathrm{CaOx}$ solution, vortexed and then incubated at $37^{\circ} \mathrm{C}$ for $30 \mathrm{~min}$. OD of the final mixtures was then read at $620 \mathrm{~nm}$ wavelength and percent inhibition of aggregation was then calculated as described for nucleation assay. ${ }^{9}$

\section{Oxalate depletion assay}

Effect of DCRE on the growth of CaOx crystals was determined by oxalate depletion assay. Varying concentrations of DCRE $(100 \mu \mathrm{g} / \mathrm{ml}, 500 \mu \mathrm{g} / \mathrm{ml}$ and $1000 \mu \mathrm{g} / \mathrm{ml}$ ) were prepared in distilled water. $\mathrm{CaOx}$ crystal slurry at a concentration of $1.5 \mathrm{mg} / \mathrm{ml}$ was prepared in a $50 \mathrm{mM}$ sodium acetate buffer ( $\mathrm{pH}$ 5.7). $4 \mathrm{mM} \mathrm{CaCl}_{2}$ solution and $4 \mathrm{mM} \mathrm{Na}_{2} \mathrm{C}_{2} \mathrm{O}_{4}$ solution $(1 \mathrm{ml}$ each) were added to $1.5 \mathrm{ml}$ Tris- $\mathrm{HCl}(10 \mathrm{mM})$ and $\mathrm{NaCl}(90 \mathrm{mM})$ buffer ( $\mathrm{pH}$ 7.4). To this was added $30 \mu \mathrm{l}$ of $\mathrm{CaOx}$ crystal slurry. The growth of $\mathrm{CaOx}$ crystals was then determined by measuring the rate of oxalate depletion from the solution at $214 \mathrm{~nm}$ wavelength for $600 \mathrm{~s}$. Effect of each concentration of DCRE on crystal growth was then determined by addition of $1 \mathrm{ml}$ of DCRE $(100 \mu \mathrm{g} / \mathrm{ml}, 500 \mu \mathrm{g} / \mathrm{ml}$ and $1000 \mu \mathrm{g} / \mathrm{ml}$ ) to the reaction mixture and change in OD was again recorded. Percent inhibition of crystal growth was then calculated as described for nucleation assay. ${ }^{10}$

\section{CaOx crystal characterization by FT-IR}

FT-IR analysis was used to confirm the CaOx crystals prepared in vitro using attenuated total reflectance (ATR) technique.

\section{Statistical analysis}

Quantitative results of all the experiments performed in triplicates were expressed as mean \pm S.E.M. (Standard Error of Mean). Statistical computations were performed on GraphPad Prism 6 software using one-way analysis of variance (ANOVA) followed by Tukey Kramer's multiple comparison test. $P$ values less than 0.05 were considered statistically significant.

\section{RESULTS}

\section{Preliminary phytochemical screening}

Percent yield of DCRE was $23.73 \%$. Qualitative phytoconstituent determination in DCRE showed the presence of carbohydrates, saponins, flavonoids, tannins and phenols.

\section{Nucleation Assay}

Addition of $\mathrm{Na}_{2} \mathrm{C}_{2} \mathrm{O}_{4}$ solution to the reaction mixture consisting of $\mathrm{CaCl}_{2}$ resulted in the formation of numerous $\mathrm{CaOx}$ crystals. Presence of DCRE $(1000 \mu \mathrm{g} / \mathrm{ml})$ in the reaction mixture produced a percent reduction in nucleation of $56.1 \pm 1.55 \%$ which was significantly higher $(P<0.01)$ than that produced by Cystone ( $41.67 \pm 1.03 \%)$ (Figure 1$)$.

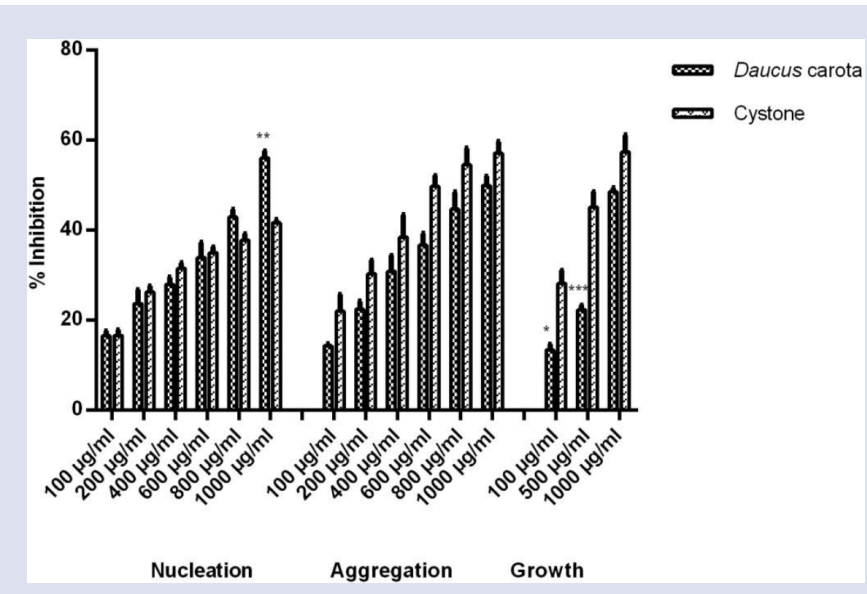

Figure 1: Effect of DCRE and Cystone on nucleation, aggregation and growth of $\mathrm{CaO}$ crystals.
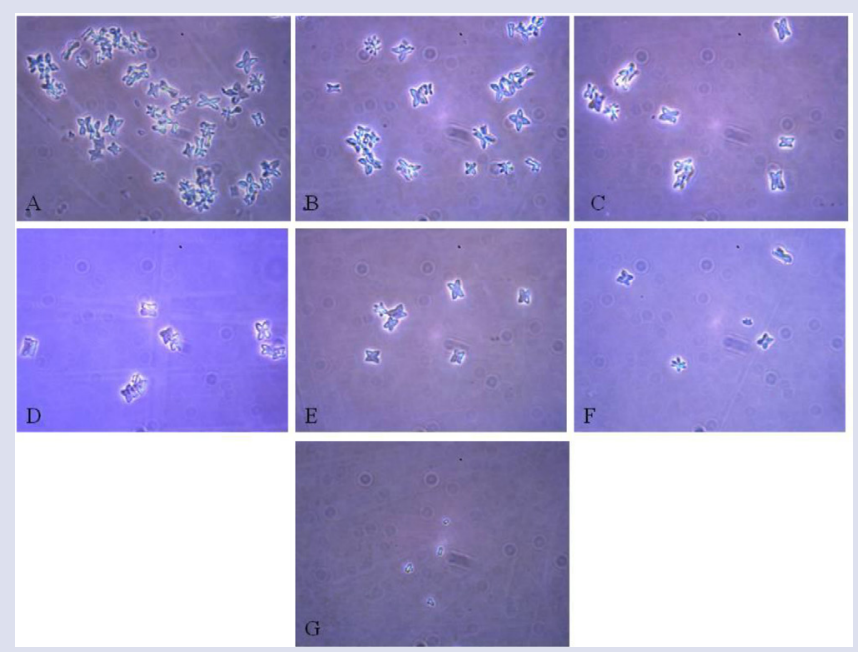

Figure 2: Representative photographs of $\mathrm{CaOx}$ crystals as observed under light microscope $(\times 1000)$ in the absence $A$, and in the presence of DCRE100 $\mu \mathrm{g} / \mathrm{ml} \mathrm{B,} 200 \mu \mathrm{g} / \mathrm{ml} \mathrm{C,} 400 \mu \mathrm{g} / \mathrm{ml} \mathrm{D,} 600 \mu \mathrm{g} / \mathrm{ml} \mathrm{E}, 800 \mu \mathrm{g} / \mathrm{ml} \mathrm{F}$, $1000 \mu \mathrm{g} / \mathrm{ml} \mathrm{G}$.

\section{Microscopy of $\mathrm{CaOx}$ crystals}

Numerous large $\mathrm{CaOx}$ monohydrate (COM) crystals of either rectangular habit or dendrites with sharp edges were predominant in the control group. DCRE at higher concentrations (Figure 2) and Cystone from lower concentrations itself (Figure 3 ) favored the formation of tetrahedral shaped calcium oxalate dihydrate (COD) crystals with smoother morphology. DCRE and Cystone also reduced the size and number of $\mathrm{CaOx}$ crystals. Percent reduction in size of $\mathrm{CaOx}$ crystals produced by DCRE (62.34\%) was comparable to that produced by Cystone (70.10\%) (Figure 4). Number of $\mathrm{CaOx}$ crystals was reduced to a far greater extent by DCRE (84.71\%) than Cystone (58.51\%) (Figure 4).

\section{Aggregation Assay}

DCRE produced a significant reduction $(P<0.0001)$ in aggregation of preformed $\mathrm{CaOx}$ crystals. Percent reduction in aggregation produced by DCRE was found to be $49.94 \pm 2.07 \%$ comparable to that of Cystone $(57.15 \pm 2.53 \%)$ at $1000 \mu \mathrm{g} / \mathrm{ml}$ concentration (Figure 1 ). 


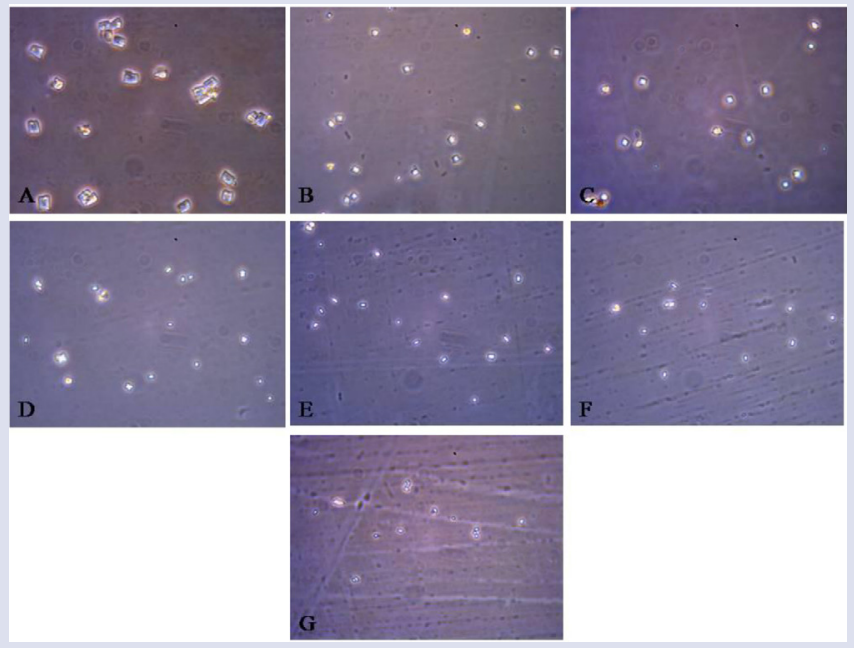

Figure 3: Representative photographs of $\mathrm{CaOx}$ crystals as observed under light microscope $(x 1000)$ in the absence $A$, and in the presence of Cystone $100 \mu \mathrm{g} / \mathrm{ml} \mathrm{B}, 200 \mu \mathrm{g} / \mathrm{ml} \mathrm{C,} 400 \mu \mathrm{g} / \mathrm{ml} \mathrm{D}, 600 \mu \mathrm{g} / \mathrm{ml} \mathrm{E}, 800 \mu \mathrm{g} / \mathrm{ml}$ $\mathrm{F}, 1000 \mu \mathrm{g} / \mathrm{ml} \mathrm{G}$.

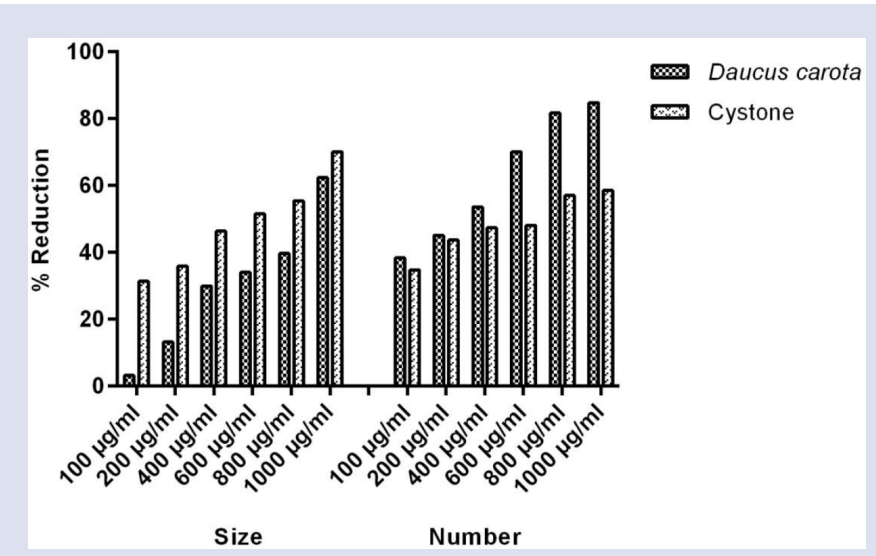

Figure 4: Effect of DCRE and Cystone on size and number of $\mathrm{CaOx}$ crystals.

\section{Oxalate depletion Assay}

Percent reduction in growth in the presence of DCRE was found to be $48.58 \pm 0.88 \%$ while, $57.44 \pm 3.7 \%$ with Cystone at $1000 \mu \mathrm{g} / \mathrm{ml}$. CaOx crystal growth inhibitory effect of DCRE was significantly lower than Cystone $(P<0.001)$ at lower concentrations but was comparable to Cystone at highest concentration (Figure 1).

\section{FT-IR characterization of CaOx crystal}

FT-IR analysis of $\mathrm{CaOx}$ crystals produced seven bands (Figure 5). Spectrum showed a broad $\mathrm{O}-\mathrm{H}$ stretching band at $3330.42 \mathrm{~cm}^{-1}$; a strong band at $1614.47 \mathrm{~cm}^{-1}$ representing $\mathrm{C}=\mathrm{O}$; another band with high absorbance at $1316.74 \mathrm{~cm}^{-1}$ representing $\mathrm{C}-\mathrm{O}$ stretch; $\mathrm{C}-\mathrm{H}$ bending at $778.65 \mathrm{~cm}^{-1}$; out-of-plane $\mathrm{O}-\mathrm{H}$ bending at $651.68 \mathrm{~cm}^{-1}$; and $\mathrm{O}-\mathrm{C}=\mathrm{O}$ in-plane bending at $511.79 \mathrm{~cm}^{-1}$ as has also been reported in previous studies. ${ }^{11-12}$

\section{DISCUSSION}

$\mathrm{CaOx}$ urolithiasis is the most prevalent type of all urinary stone diseases. Key events involved in its pathological biomineralization include crystal

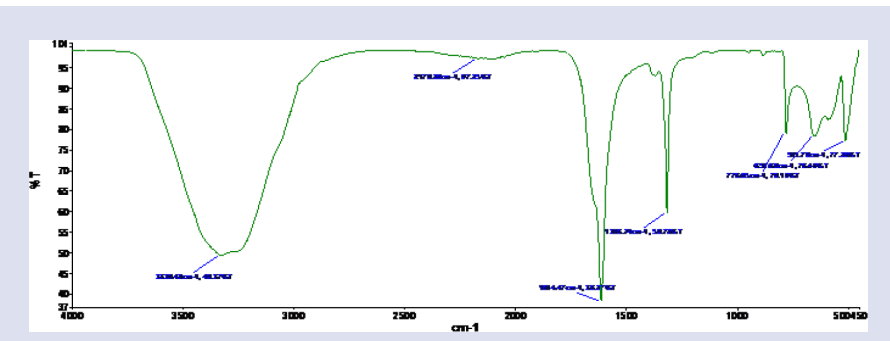

Figure 5: FT-IR spectra of seed $\mathrm{CaOx}$ crystals.

nucleation, growth and aggregation. ${ }^{13}$ Present study was designed to address these key events involved in $\mathrm{CaOx}$ stone formation as a means to investigate the efficacy of $D$. carota roots as an antiurolithiatic.

Nucleation is a prerequisite in the pathogenesis of $\mathrm{CaOx}$ urolithiasis. Nucleation basically marks a thermodynamically driven event of phase change wherein dissolved substances in a supersaturated solution spontaneously crystallize. ${ }^{13-14}$ Similar phase change and formation of $\mathrm{CaOx}$ crystals was witnessed while carrying out nucleation assay. Significant inhibition in the nucleation of $\mathrm{CaOx}$ crystals was observed in the presence of DCRE which was even better than in the presence of Cystone. This suggests the anticrystallization activity of DCRE against $\mathrm{CaOx}$ crystallization. One possible mechanism of anticrystallization activity of DCRE could be its ability to complex with free calcium and oxalate ions, thus preventing the formation of $\mathrm{CaOx}$ complexes, as has also been suggested for Sarghassum wightti. ${ }^{15}$

$\mathrm{CaOx}$ polymorphism is a common phenomenon and of utmost significance in urolithiasis. COM and COD crystals are commonly found in $\mathrm{CaOx}$ uroliths. ${ }^{16}$ Of the two polymorphs, COM is thermodynamically more stable with more aggregatory and adhesive tendency. Hence, COM tends to form large crystal aggregates and adheres strongly to renal epithelial tissue, injuring the same. Therefore, of the two polymorphs, COM significantly promotes crystal retention and eventual stone formation. ${ }^{17}$ Therefore, a transformation from COM to COD is advocated as a crucial step in inhibition of calculi formation. ${ }^{16}$ In present study, DCRE also promoted transformation of pointy edged dendritic COM crystals to smoother edged COD crystals of extremely reduced size and number. Reduction in size of $\mathrm{CaOx}$ crystals is critical as smaller crystals tend to spontaneously pass out in urine. ${ }^{18}$

Growth of $\mathrm{CaOx}$ crystals marks the event of deposition of crystal forming ions present in the supersaturated solution on preformed $\mathrm{CaOx}$ crystal lattice. ${ }^{13,19}$ This event of growth of $\mathrm{CaOx}$ crystals was also tracked in the present study. DCRE exhibited growth inhibitory activity as was also confirmed from the crystals of reduced size produced in the presence of DCRE.

Aggregation of crystals marks the process wherein numerous crystals in the solution come together and adhere forming large crystal agglomerates. Aggregation is a key determinant of crystal retention as large crystal agglomerates are the ones that produce renal tubular obstruction thereby promoting stone formation..$^{13}$ DCRE showed significant inhibitory effect on $\mathrm{CaOx}$ crystal aggregation.

Qualitative phytochemical estimation of DCRE revealed the presence of flavonoids, phenolic compounds, saponins and tannins. These phytoconstituents are of utmost significance for inhibiting urinary stone formation. Saponins possess antilithic properties ${ }^{9}$ and are known to disintegrate mucoproteins that are crucial components of stone matrix..$^{20}$ Tannins and polyphenols inhibit $\mathrm{CaOx}$ crystal formation as well as dissolve the preformed $\mathrm{CaOx}$ crystals by aiding calcium complexation. ${ }^{21}$ 
Flavonoids also possess $\mathrm{CaOx}$ crystal dissolution potency. Phenolics and flavonoids exhibit antioxidant activity. ${ }^{20}$ Therefore, the anti-crystallization, anti-aggregatory and crystal growth defying activity of DCRE would have been an outcome of these phytoconstituents present in DCRE.

As COM crystals are the most predominant form of all the polymorphs of $\mathrm{CaOx}$ found in kidney stones, formation of COM crystals was a mandatory requirement to test the efficacy of DCRE against COM crystallization. In order to confirm the formation of COM crystals to be utilized for aggregation and growth assays, $\mathrm{CaOx}$ crystal characterization was carried out by FT-IR spectrophotometry. Formation of COM crystals was confirmed from the sharp peak at $778.65 \mathrm{~cm}^{-1}$ and a comparatively broader peak at $651.68 \mathrm{~cm}^{-1}$ which are characteristic of COM crystals. Whereas, a sharp peak at about $910 \mathrm{~cm}^{-1}$ is known to be specific to COD crystals. ${ }^{22}$ In addition, peaks at $3330.42,1614.47,778.65$ and $511.79 \mathrm{~cm}^{-1}$ that were prominent in the FT-IR spectrum of $\mathrm{CaOx}$ crystals closely correlate to the typical COM identification bands. ${ }^{23}$

It is true that in vitro data cannot be simply extrapolated to infer results of more complex in vivo systems, but in vitro studies give an insight into the activity related efficacy of tested compounds or extracts. Present study also demonstrated prominent inhibitory activity of DCRE against $\mathrm{CaOx}$ crystallization.

\section{CONCLUSION}

Findings of the present study clearly demonstrate antiurolithiatic potential of DCRE against $\mathrm{CaOx}$ urolithiasis in vitro. DCRE showed prominent inhibition of all the phases of $\mathrm{CaOx}$ stone formation viz. nucleation, growth and aggregation, and favored the formation of more amenable COD crystals. Although further in vivo and clinical explorations are required to confirm the efficacy of D. carota as an antiurolithiatic, still, considering the vast consumption and availability of $D$. carota all around the globe together with its antilithic potential, D. carota could serve as an easily accessible and beneficial alternative or adjunctive treatment for $\mathrm{CaOx}$ urolithiasis.

\section{ACKNOWLEDGEMENT}

First author is thankful to the Department of Science and Technology (Innovation in Science Pursuit for Inspired Research (INSPIRE) program), Government of India, for providing financial assistance [grant number DST/INSPIRE Fellowship/2014/IF140276] to carry out the related research work. The author is also thankful to Botanical Survey of India (BSI), Northern Regional Centre, Dehradun for the authentication of plant samples. Authors also thank Head of the Department Mr. B. K. Singh and Dr. L.S. Rautela of Department of Pharmaceutical Sciences, Kumaun University, Nainital for their undeniable support to carry out the research work.

\section{CONFLICT OF INTEREST}

The authors declare no conflict of interest.

\section{ABBREVIATIONS}

ATR: Attenuated total reflectance; CaOx: Calcium oxalate; COD: Calcium oxalate dihydrate; COM: Calcium oxalate monohydrate; DCRE: Daucus carota root extract; FT-IR: Fourier transform infrared spectroscopy; OD: Optical density.

\section{REFERENCES}

1. Harper JD, Cunitz BW, Dunmire B, Lee FC, Sorensen MD, Hsi RS, et al. First in human clinical trial of ultrasonic propulsion of kidney stones. J Urol. 2016;195(4):956-64.

2. Mittal A, Tandon S, Singla SK, Tandon C. Mechanistic insights into the anti-lithiatic proteins from Terminalia arjuna: a proteomic approach in urolithiasis. PLoS One. 2016;11(9):e0162600.

3. Mittal A, Tandon S, Singla SK, Tandon C. In vitro inhibition of calcium oxalate crystallization and crystal adherence to renal tubular epithelial cells by Terminalia arjuna. Urolithiasis. 2016;44(2):117-25.

4. Sharma KD, Karki S, Thakur NS, Attri S. Chemical composition, functional properties and processing of carrot-a review. J Food Sci Technol. 2012;49(1):22-32.

5. Sodimbaku V, Pujari L, Mullangi R, Marri S. Carrot (Daucus carota L.): Nephroprotective against gentamicin-induced nephrotoxicity in rats. Indian J Pharmacol. 2016;48(2):122-7.

6. Lev E, Dolev E. Use of natural substances in the treatment of renal stones and other urinary disorders in the medieval levant. Am J Nephrol. 2002;22(2-3):172-9.

7. Aqil $F$, Ahmad I. Broad-spectrum antibacterial and antifungal properties of certain traditionally used Indian medicinal plants. World J Microbiol Biotechnol. 2003;19(6):653-7.

8. Khandelwal KR. Practical pharmacognosy: techniques and experiments. 19th ed. Pune: Nirali Prakashan; 2008.

9. Patel PK, Patel MA, Vyas BA, Shah DR, Gandhi TR. Antiurolithiatic activity of saponin rich fraction from the fruits of Solanum xanthocarpum Schrad. and Wendl. (Solanaceae) against ethylene glycol induced urolithiasis in rats. J Ethnopharmacol. 2012;144(1):160-70.

10. Chaudhary A, Singla SK, Tandon C. In vitro evaluation of Terminalia arjuna on calcium phosphate and calcium oxalate crystallization. Indian J Pharm Sci. 2010;72(3):340-5

11. Sekkoum K, Cheriti A, Taleb S, Belboukhari N. FTIR spectroscopic study of human urinary stones from El Bayadh district (Algeria). Arab J Chem. 2016;9(3):330-4.

12. Bhattacharyya S, Sharma G, Mandal AK, Singh SK. Analysis of the chemical composition of urinary calculi using Fourier transform infrared spectroscopy: a preliminary study. J Postgrad Med Edu Res. 2014;48(3):128-31.

13. Aggarwal KP, Narula S, Kakkar M, Tandon C. Nephrolithiasis: molecular mechanism of renal stone formation and the critical role played by modulators. Biomed Res Int. 2013;292953.

14. Basavaraj DR, Biyani CS, Browning AJ, Cartledge JJ. The role of urinary kidney stone inhibitors and promoters in the pathogenesis of calcium containing renal stones. EAU-EBU update series. 2007;5(3):126-36

15. Sujatha D, Singh K, Vohra M, Kumar KV, Sunitha S. Anti-lithiatic activity of phlorotannin rich extract of Sarghassum wightii on calcium oxalate urolithiasisin vitro and in vivo evaluation. Int Braz J Urol. 2015;41(3):511-20.

16. Wesson JA, Worcester EM, Wiessner JH, Mandel NS, Kleinman JG. Control of calcium oxalate crystal structure and cell adherence by urinary macromolecules. Kidney Int. 1998;53(4):952-7.

17. Sheng $X$, Ward MD, Wesson JA. Crystal surface adhesion explains the pathological activity of calcium oxalate hydrates in kidney stone formation. J Am Soc Nephrol. 2005;16(7):1904-8.

18. Atmani F, Khan SR. Effects of an extract from Herniaria hirsuta on calcium oxalate crystallization in vitro. BJU Int. 2000;85(6):621-5.

19. Ratkalkar VN, Kleinman JG. Mechanisms of stone formation. Clin Rev Bone Miner Metab. 2011;9(3-4):187-97.

20. Sikarwar I, Dey YN, Wanjari MM, Sharma A, Gaidhani SN, Jadhav AD. Chenopodium album Linn. leaves prevent ethylene glycol-induced urolithiasis in rats. $J$ Ethnopharmacol. 2017;195:275-82.

21. Doddola S, Pasupulati H, Koganti B, Prasad KV. Evaluation of Sesbania grandiflora for antiurolithiatic and antioxidant properties. J Nat Med. 2008;62(3):300-7.

22. Martin X, Smith LH, Werness PG. Calcium oxalate dihydrate formation in urine. Kidney Int. 1984;25(6):948-52.

23. Deng F, Ouyang JM. Comparative investigations of ultrafine crystals in urine of healthy human and lithogenic patients. Mater Sci Eng C. 2006;26(4):688-91. 
GRAPHICAL ABSTRACT

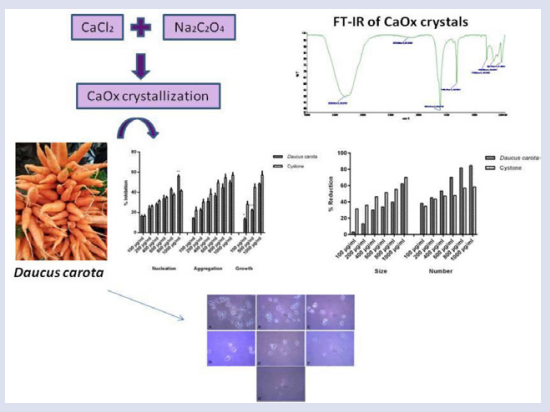

\section{SUMMARY}

- Hydroethanolic extract of Daucus carota roots produced significant inhibition of nucleation, growth and aggregation of calcium oxalate crystals.

- Possible mechanism involved could be complexation of calcium and oxalate ions by D. carota extract and anticrystallization and antioxidant actions of the phytoconstituents of $D$. carota.

\section{ABOUT AUTHORS}

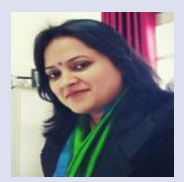

Dr. Archana Negi Sah: Is a Graduate in Pharmaceutical Sciences and Basic Sciences, Post Graduate in Herbal Drugs Technology and Ph.D. in Pharmacy. She is currently working as Senior Assistant Professor in Department of Pharmaceutical Sciences, Faculty of Technology, Kumaun University, Bhimtal Campus, Nainital, Uttarakhand, India from more than a decade. Dr. Sah is a recipient of the UGC fellowship for the PG course and received first prize for paper presentation. She is supervising 4 Ph.D. Scholars and has supervised more than 20 M. Pharm. students in their research work. Dr. Sah is a member of different Professional and academic bodies, published chapters, peer reviewed national and international papers and delivered a range of presentations in different International and National Seminars/Conferences.

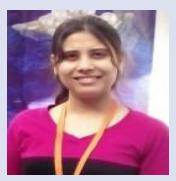

Sweta Bawari: Is a Doctoral student and INSPIRE Fellow at Department of Pharmaceutical Sciences, Faculty of Technology, Kumaun University, Bhimtal Campus Nainital, Uttarakhand, India. She has obtained her Master of Pharmacy in Pharmacology. Her area of research is focused on pharmacological activities and evaluation of natural products.

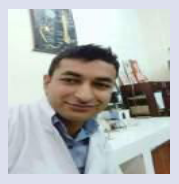

Devesh Tewari: Is a Doctoral student and has submitted his thesis in the field of Ethnopharmacology and Pharmacognosy in Department of Pharmaceutical Sciences, Faculty of Technology, Kumaun University, Bhimtal Campus Nainital, Uttarakhand, India. He has obtained his Master of Pharmacy in Pharmacognosy. He is the author of several publications in various national and international journals and reviewer of various journals of high international repute. 